\section{B A Institute of \\ YK Business Administration \\ 六下 \\ Karachi \\ Leadership and Ideas for Tomorrow}

Business Review

Volume 16 Issue 2 July-December 2021

\title{
Role of organizational capital at different phases of business's life cycle: a study of PSX companies
}

\author{
Zahid Bashir \\ Department of Commerce, University of Gujrat \\ Ghulam Ali Bhatti \\ Noon Business School, University of Sargodha, Pakistan \\ Sobia Arshad \\ Department of Management Sciences, University of Gujrat
}

Follow this and additional works at: https://ir.iba.edu.pk/businessreview

Part of the Corporate Finance Commons, Finance and Financial Management Commons, and the Management Sciences and Quantitative Methods Commons

\section{(c) (1)}

This work is licensed under a Creative Commons Attribution 4.0 International License.

\section{Recommended Citation}

Bashir, Z., Bhatti, G. A., \& Arshad, S. (2022). Role of organizational capital at different phases of business's life cycle: a study of PSX companies. Business Review, 16(2), 60-76. Retrieved from https://doi.org/ 10.54784/1990-6587.1428

This article is brought to you by iRepository for open access under the Creative Commons Attribution 4.0 License and is available at https://ir.iba.edu.pk/businessreview/vol16/iss2/4. For more information, please contact irepository@iba.edu.pk. 


\title{
Role of Organizational Capital at Different Phases of Businesss life cycle: A study of PSX Companies
}

\author{
Zahid Bashir • Ghulam Ali Bhatti . \\ Sobia Arshad
}

\begin{abstract}
The goal of this study was to examine the association between Business Life Cycle phases and organizational capital using PSX index companies. Mainly, the study investigates the relationship of organizational capital phases during different phases of the life cycle and its comparison with high and low organizational capital. To fulfill this objective, we have gathered PSX index of 56 companies with yearly observations ranging from 2011-2020. For estimation, a multinomial logistic model was used due to categories of the dependent variable. The results indicate that organizational capital is positively significant at the maturity phase but negatively significant at the introduction, growth, shakeout, and decline phase of the Business Life Cycle. Business Life Cycle and size, ROE, Capex, and leverage significantly but negatively affect the Business Life Cycle, whereas age and ATO significantly affect Business Life Cycle phases. The results vary with different phases of the Business Life Cycle. For future study, the study recommended that the scholar increase the number of observations for more accurate results or alternatively, use a different proxy for measuring organizational capital.
\end{abstract}

Keywords Organizational Capital, Firms Life Cycle, PSX companies, Multinomial logistic regression

\section{Introduction}

A Business Life Cycle is a set of phases in which companies move from one phase to another due to the performance of business operations. It is divided

\footnotetext{
Zahid Bashir

University of Gujrat

E-mail: zahid.bashir@uog.edu.pk

Ghulam Ali Bhatti

University of Sargodha, Pakistan

Sobia Arshad

University of Gujrat

(C)Bashir, Z., Bhatti, A. G., and Arshad, S. 2022
} 
into five subcategories: introduction, growth, maturity, shake-out, and decline. Mueller (1972) stated that a moderately all-around characterized life cycle is essential to the firms theory of profits life cycle. The theory of life-cycle has vital ramifications in regards to the effectiveness of the activity of the capital market. Life cycle theory of firm defined as resources, abilities, tactics, constructions, and working of the firm change altogether with specific phases of growth. Each phase is described by changes in firm's environment, tactics, structure and basic leadership style (Miller and Friesen 1984; Quinn and Cameron 1983). The developed phase of a company's life cycle, for the most part, results in a move toward maximizing productivity with efficiency, diminishing uncertainty and declining venture consumption. It is also marked by noteworthy distribution of capital to investors, and improved administration structures (Barclay and Smith 2005; Filatotchev et al 2006). Similarly, according to Evenson and Westphal (1995), the knowledge utilized to integrate human talents as well as capital investments as platforms for generating and distributing needs for self-items is referred to it as Organization Capital.

Lev et al (2009) argued that firm expenditures of SG\&A create corporate value through the construction of organization capital. Similarly, Black and Lynch (2009) classified organizational capital into three different categories: workforce development, employee engagement, and employee participation. Additionally, the knowledge or intelligence embedded inside an organization's core personnel that boosts efficiency is known as organizational capital, making it a catalyst for growth (Eisfeldt and Papanikolaou 2013). However, according to the argument of Lev et al (2009), the majority of spending that enhances a firm's capital is associated with IT spending, personnel staff costs, and marketing expenses. When a company is in the infancy stage, it does not have access to external finance. In addition, it is suffering from limited capital (Atkeson and Kehoe 2005). The organization finds an easy way to spend effort and time for increasing performance of the firm with the help of developing organizational culture, language, the process of organization, practices, and know-how of company (Hasan et al 2018).

Organizational capital is one of the most important elements which helps the organization to improve productivity and increase efficiency. Expenses from the OC are more than thirty-three percent of expenses from physical capital (PC), net of new investment (Hasan et al 2018). Different kinds of research were conducted for the Business Life Cycle; however, there is a deficiency in the literature of organization capital and phases of FLC in Pakistan. The current study finds how organizational capital affects the development of a company in different phases of life cycle. Organizational capital is needed to investigate in Pakistani firms because many corporate firms are established with the support of human capital (Flavin et al 2020). In Pakistani companies, job turnover ratio is high due to a lack of growth opportunities; employees often switch their jobs for better positions, better finances, and to improve skills (Shah et al 2021). If an employee leaves or resigns from an organization, then its human capital and capabilities to link with that organization are also lost. A firm's capital, in general, plays a critical function for every business at various stages of its life cycle (Ding et al 2021). 
The present investigation intends to achieve the accompanying main goals; a) To investigate the link between organizational capital and the different phases of the business life cycle for PSX-listed companies.

b) To investigate the asymmetrical behavior of organizational capital at various stages of the business's life cycle.

The subsequent questions about research can indeed be developed to examine the investigation by taking into consideration the existing study's goal:

i. What's the link between organizational capital with different stages of a business's life cycle?

ii. How does organizational capital operate asymmetrically at various stages of a company's life cycle?

Organization capital is an intangible asset and the firm will grow when organization capital will be maintained. If the company maintains its process for selling, advertisement channels, employees training, and other developing plansall these efforts will increase the companys reputation and firm performance. Moreover, these strategies enhance the firm's productivity and firm recognition. However, if organization capital is not maintained, then the firm will suffer. It won't have access to good investment, will face a declining reputation and have limited growth opportunities. Good organizational capital is also important because it helps the company progress from its start-up period to the developmental process. Each stage of the business life cycle necessitates a solid management procedure, as well as the efficacy as well as reliability of firm production.

\section{Literature review}

Organizational capital permits the profitable use of both resources and capabilities, such as equipment, inventions, branding, and intellectual resource (Black and Lynch 2009). Similarly, organizational capital is a company's most valuable intangible asset. Equipment, manpower, patents, and other enterprise capabilities are dormant by itself (Watson et al 2021. Atkeson and Kehoe (2005) measured the total size of organization capital in an economy. Second, by applying the method for adjustment, they surveyed the capacity of their model to copy highlights of the real economy. Third, they broke down the firms from the item side. Firms in the development phases are more worried about boosting the advantages from the current load of organizational capital. However, according to the study of Lev and Radhakrishnan (2009), organizational capital is related to the performance of stock and long-term operations. Organization capital is important because it permits beneficial connection among intangible and tangible assets in making monetary value and development. Additionally, Eisfeldt and Papanikolaou (2013) found that businesses with far more organizational capital generate higher returns, have stronger Tobin's Q as well as normalized yield on risk, and even had higher CEO returns.

Organization capital impact checked by Hasan et al (2018) took a resourcebased view that defines basic assets as those that are not tradable, hard to be copied and substituted. Chan et al (2019) results show that firms decrease 
compensation to top-executive after analyst coverage decreases due to brokerage compensation house merger or closure. Jona-Lasinio et al (2019) concluded that organizational capital, as well as training, had the greatest positive impact on value adaptation. Marwick et al (2020) stated that organizations face more financial limitations including working capital volatility, and discovered a link between organizational capital, cash as well as capital reserves. The findings revealed that organizational capital does have a strong positive relationship with the entire life cycle of a business even during the introduction as well as decline phases. Moreover, it also has an inverse relation with the entire life cycle of a business during growth stage phases.

Dynamic resource-based theory recommended that competitive merit and demerit as far as assets and capacities advance after some decades do so in various ways (Helfat and Peteraf 2003). Although mature organizations have lowered their investment in comparison to growing companies, organizations keep investing to sustain capital (Bhattacharya et al 2020; Hambrick et al 1982; Jovanovic 1982). Dickinson (2011) built an FLC measure by using data of firms' cash flow statements. She claimed cash flows of a firm detect variances in a business's profitability, development and risk. As a result, cash flow from operations, investment, and financing can be used to categorize businesses throughout life cycle stages; introduction, growth, maturity, shake-out, and decline. The pattern is as follows:

If operating and investing cash flow is less than zero but financing cash flow is greater than zero then $\mathrm{OCF}<$ zero, ICF $<$ zero and FCF zero.

Atkeson and Kehoe (2005) proposed that holders incur large spending in OC in the first phase of the life cycle so they could secure and grow organization rents in the future. When operating cash flow is negative, it shows that the firm is in the introduction phase and a firm has no access to internal funds to finance its company operations. In that case, the company needs external financing and the positive cash flow is $\mathrm{FCF}>0$. At the phase of firm introduction, investing activities are ICF < zero, as it invests in long-term growth (Carlin et al 2012; Hasan et al 2018). External investment in the OC can resolve their data shortfall complications effectively. In short, the pattern of cash flow (OCF $<$ zero, ICF $<$ zero, and $\mathrm{FCF}>$ zero) with more organization capital makes these organizations an appropriate contender to be in the introduction phase (Cui and Mak 2002).

$H_{1}^{O}$ :Firms with lower OC are possibly to be in the stage of introduction.

$H_{1}^{A}$ : Firms with higher $\mathrm{OC}$ are possibly to be in the stage of introduction.

If operating and financing cash flow is greater than zero but investing cash flow is less than zero, then OCF zero, ICF < zero and FCF zero. If operating cash flow is greater than zero and investing and financing cash flow is also greater than zero OCF zero, ICF < zero and FCF < zero.

During the growth phase and maturity phase, organizations already maintain the new strategies for product's upgradation and modification. Organizations also know their competitors and understand how to differentiate their product from them. In particular, for developing organizations, large initial capital 
costs are incurred even during the introduction stage of the life cycle, which are not recouped during the development and stability phases (Li et al 2021). The organization in the growth stage continues to support itself with loans, before going for capital spending, additional growth, as well as advancement, which culminates in FCF $>$ zero- indicating positive funding. In summary, organizations in the growth and maturity phases do not spend significantly more on organizational capital; instead, they seek to capitalize more intangibles and take advantage of the latest OC benefits (Hasan et al 2018). Consequently, the subsequent patterns of cash flow for growth and maturity are $\mathrm{OCF}>$ zero, $\mathrm{ICF}<$ zero and $\mathrm{FCF}>$ zero and $\mathrm{OCF}>$ zero, $\mathrm{ICF}<$ zero, and $\mathrm{FCF}<$ zero.

$$
\begin{gathered}
H_{2}^{O} \text { :Firms with higher OC are more possibly to be in the stage of maturity } \\
\text { growth. } \\
H_{2}^{A} \text { : Firms with lower OC are more possibly to be in the stage of maturity } \\
\text { growth. }
\end{gathered}
$$

The shake-out stage involved the remainder of the company's years. Existing studies specify that organization capital mixes the expertise of human and physical capital, which permits the organization to attain effectual manufacturing and stable operation of firms and allows firms to perform better in the future (Attig and Cleary 2014; Lev et al 2009). Therefore, irrespective of whether first-phase companies spend more than that in organizational capital, they are much less (more) inclined to progress into the intro, shake-out, even decline (growth/maturity) stages in the hereafter, according to the present study.

\section{$H_{3}^{O}$ :Companies investing more within OC have become less inclined to go} through the intro, shake-out, even decline stages later on.

$H_{3}^{O}$ :Businesses that engage more in OC seem to be more inclined to go to the growing or maturity stages.

If operating cash flow is less than zero, investing cash flow is greater than zero but financing cash flow is less than or equal or greater than or equal to zero, then OCF < zero, ICF zero and FCF or zero. Organizations in the decline phase are classified according to the profit margin. If the profit margin of a company is very low or negative, then efficiency, effectiveness, and capacity to utilization in the firm is also very lowDickinson 2011. If firms dont compete with others in the case of business innovation, process, practice, and culture, the existence of those firms become irrelevant in the market(Habib and Hasan 2017). In other words, enterprises that are in initial or growing stages and have large mortality rates may switch from growth to decline stage. Instead of reinvesting for company expansion, organizations in this phase prioritize profit distribution to investors (DeAngelo et al 2006). Therefore, according to previous researchers point of view, the current study develops two hypotheses for the decline phase hypothesis:

$$
\begin{aligned}
& H_{4}^{O} \text { :Firms with lower OC are possibly to be in the stage of decline. } \\
& H_{4}^{O} \text { :Firms with higher OC are possibly to be in the stage of decline. }
\end{aligned}
$$

Business Review: (2021) 16(2):60-76 


\subsection{Theoretical Model}

According to Hasan and Habib (2017a), a diverse impact of organizational capital is noted for different stages of firms life cycle. They found a positive role of organizational capital during growth and maturity stages. However, they noted negative impact of the same at introduction, decline, and shakeout stages of business life cycle. Furthermore, Hasan et al (2018) found similar positive impact of organizational capital during maturity stage and negative in the remaining phases of business life cycle. Additionally, Akbar et al (2019)) found that firms with the higher maturity level strongly benefits from enhanced level of organizational capital. Further research studies provided similar diverse findings for the impact of organizational capital on firms life cycles different stages (Marwick et al 2020; Ren and Song 2021; Saravia et al 2016; Watson et al 2021).

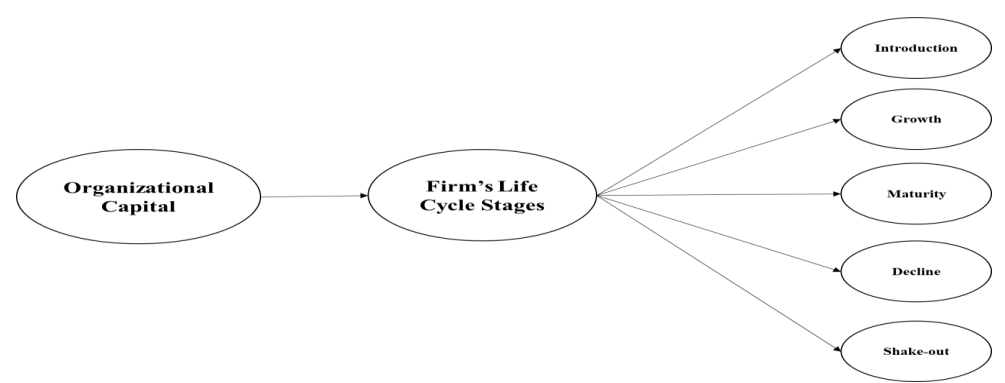

Fig. 1: Theoretical Model (Firm Life Cycle Theory

Figure 1 highlights the impact of organizational capital on different stages of firms life cycle: introduction, growth, maturity, decline, and shake-out. The study aims to investigate the behavior and impact of organizational capital for these stages of firms life cycle for the non-financial manufacturing companies in Pakistan.

\section{Methodology}

\subsection{Data and methodology}

For the present research investigation, the required set of data was obtained using the firms cash flow statements, balance sheets from the companies website. The study covers a data period ranging from 2011 to 2020 . The sample contains 56 manufacturing firms which are part of PSX index companies. The study uses unbalanced panel data with pooled format of dataset. The remaining data related to shares price and consumer price index is downloaded from the PSX website and WDI for the period of study. The business life cycle is used as the dependent variable in this study. It is measured using different researchessome researchers construct categorical variables for measuring firms' life cycle. 
Others measure it through cash flow patterns while some create different life cycle phases from operating, investing, and financing patterns of cash flows. The current study uses organization capital as an independent variable. An organization's capital consists of all those expenses which are incurred for the reputation, growth, and well-known of the organization. Organization capital stock is calculated with the help of the perpetual inventory method. The study examines the business's capital formation cyclically by accumulating the deflating price of SG\&A expenditures.

$$
\text { OCstock }_{i t}=\left(1-\text { Depr }_{o c}\right) * \text { OCstock }_{i t-1}+\frac{S G \& A_{i t}}{C P I_{t}}
$$

In equation 1, DeproC shows the depreciation rate of OC and the Consumer price index denoted by $C P I_{t}$. To implement the law of motion in equation (i), firstly research chooses the initial stock according to

$$
\text { OCstock }_{i t}=\frac{S G \& A_{i t}}{g}+\text { Depr }_{o c}
$$

The above equation shows $\mathrm{g}$ is the firm SG\&A expenses growth rate and dep for depreciation. Research sets depreciation of organization capital and growth of SG\&A.

Multivariate logistic regression was employed in this investigation, with the following assumption: it is utilized whenever the output variable is categorical, with two or more mutually exclusive categories (Hasan et al 2018). Since the response variable is indeed the business life cycle, which is separated into 5 different stages, such a model is appropriate for existing research. The following is a quantitative model. As just predictor variables, BLC stands for the business life cycle. BLC contains five subcategories which are introduction, growth, maturity shake-out and decline, Organization capital (OC) is used as an independent variable and this research also includes some control variables size of the firm (S), Market to book ratio (MTB) Leverage (L), Return on Equity (R), Change in sales (S), Capital expenditure (C), Firm Age (Ag), Assets turnover Ratio (AT), and Advertisement expense (Ad).

$\ln \left(\frac{P_{\text {intr }}}{P_{F L C}}\right)=\frac{1}{1+e^{-\left(\alpha+\beta_{1} O C+\beta_{2} S+\beta_{3} M T B+\beta_{4} L+\beta_{5} R+\beta_{6} \Delta S+\beta_{7} C+\beta_{8} A g+\beta_{9} A T+\beta_{10} A D\right)}}$

$$
\operatorname{prob}(\text { intro })=\frac{1}{1+e^{-\left(\alpha+\beta_{1} O C+\beta_{2} S+\beta_{3} M T B+\beta_{4} L+\beta_{5} R+\beta_{6} \Delta S+\beta_{7} C+\beta_{8} A g+\beta_{9} A T+\beta_{10} A D\right)}}
$$

$$
\ln \left(\frac{P_{\text {grow }}}{P_{F L C}}\right)=\frac{1}{1+e^{-\left(\alpha+\beta_{1} O C+\beta_{2} S+\beta_{3} M T B+\beta_{4} L+\beta_{5} R+\beta_{6} \Delta S+\beta_{7} C+\beta_{8} A g+\beta_{9} A T+\beta_{10} A D\right)}}
$$

$$
\operatorname{prob}(\text { intro })=\frac{1}{1+e^{-\left(\alpha+\beta_{1} O C+\beta_{2} S+\beta_{3} M T B+\beta_{4} L+\beta_{5} R+\beta_{6} \Delta S+\beta_{7} C+\beta_{8} A g+\beta_{9} A T+\beta_{10} A D\right)}}
$$


Table 1: Variable Measurements

\begin{tabular}{|c|c|c|}
\hline Variables & Measurements & References \\
\hline $\begin{array}{l}\text { Business Life } \\
\text { Cycle (BLC) }\end{array}$ & $\begin{array}{l}\text { Introduction }=1 \text { : } \\
\mathrm{OCF}<0, \mathrm{ICF}<0 \text { and FCF } 0 \\
\text { Growth }=2 \text { : } \\
\mathrm{OCF} 0, \mathrm{ICF}<0 \text { and FCF } 0 \\
\text { Maturity }=3 \text { : } \\
\mathrm{OCF} 0, \mathrm{ICF}<0 \text { and FCF }<0 \\
\text { Shake-out }=4 \text { : } \\
\text { The remaining firm years } \\
\text { Decline }=5 \text { : } \\
\mathrm{OCF}<0, \mathrm{ICF} 0 \text { and FCF or } 0\end{array}$ & $\begin{array}{l}\text { Dickinson (2011); Hasan } \\
\text { and Habib (2017b); } \\
\text { Hasan et al (2017) }\end{array}$ \\
\hline $\begin{array}{l}\text { Retain Earning } \\
\text { Organization Capi- } \\
\text { tal (OC) }\end{array}$ & $\begin{array}{l}\frac{\text { RetainedEarning }}{\text { OCqalAssets }} \\
\frac{\text { TCapital }}{\text { Total Assets }}\end{array}$ & $\begin{array}{l}\text { Eisfeldt and Papaniko- } \\
\text { laou (2013) }\end{array}$ \\
\hline Size $(S)$ & $\ln ($ Total Assets $)$ or $\ln ($ Total Sales $)$ & $\begin{array}{l}\text { Al-Hadi et al (2019); } \\
\text { Dickinson (2011); Zafar } \\
\text { et al (2017) }\end{array}$ \\
\hline $\begin{array}{l}\text { Market to Book } \\
\text { Ratio (MTB) }\end{array}$ & $\frac{\text { Equity (Market Value })}{\text { Equity(BookValue })}$ & $\begin{array}{l}\text { Dickinson (2011); Habib } \\
\text { et al (2018); Habib and } \\
\text { Hasan (2017) }\end{array}$ \\
\hline Leverage (L) & $\frac{(\text { Short Term Debts }+ \text { Long Term Debts })}{\text { Total Assets }}$ & $\begin{array}{l}\text { Al-Hadi et al (2019); } \\
\text { Habib et al (2018) }\end{array}$ \\
\hline $\begin{array}{l}\text { Return on Equity } \\
\text { (R) }\end{array}$ & $\frac{\text { Operating Income }}{\text { Total Equity }}$ & $\begin{array}{l}\text { Hasan et al (2018); Hsu } \\
(2018)\end{array}$ \\
\hline $\begin{array}{l}\text { Change in } \\
\text { sales }(S)\end{array}$ & $\frac{\Delta \text { sales }}{\text { Total Sales }}$ & $\begin{array}{l}\text { Attig and Cleary (2014); } \\
\text { Hasan et al (2018) }\end{array}$ \\
\hline $\begin{array}{l}\text { Capital } \\
\text { Expenditure }(\mathrm{C})\end{array}$ & $\frac{\text { Capital Expenditure }}{\text { Total Assets }}$ & $\begin{array}{l}\text { Habib and Hasan (2017); } \\
\text { Leung et al (2018) }\end{array}$ \\
\hline Age $(\mathrm{Ag})$ & $\operatorname{Ln}\left(1+\right.$ Firm $^{\prime}$ s Age $)$ & $\begin{array}{l}\text { Habib and Hasan (2017); } \\
\text { Hsu (2018) }\end{array}$ \\
\hline $\begin{array}{l}\text { Assets Turnover } \\
\text { Ratio (AT) }\end{array}$ & $\frac{\text { Net Sales }}{\text { Total Assets }}$ & $\begin{array}{l}\text { (Dickinson 2011; Hasan } \\
\text { et al 2018) }\end{array}$ \\
\hline Advertising (AD) & $\frac{\frac{\text { Advertisment Expenses }}{\text { Total Sales }}}{4}$ & (Hasan et al 2018) \\
\hline
\end{tabular}

$\ln \left(\frac{P_{\text {matu }}}{P_{F L C}}\right)=\frac{1}{1+e^{-\left(\alpha+\beta_{1} O C+\beta_{2} S+\beta_{3} M T B+\beta_{4} L+\beta_{5} R+\beta_{6} \Delta S+\beta_{7} C+\beta_{8} A g+\beta_{9} A T+\beta_{10} A D\right)}}$

$\operatorname{prob}($ matu $)=\frac{1}{1+e^{-\left(\alpha+\beta_{1} O C+\beta_{2} S+\beta_{3} M T B+\beta_{4} L+\beta_{5} R+\beta_{6} \Delta S+\beta_{7} C+\beta_{8} A g+\beta_{9} A T+\beta_{10} A D\right)}}$

$\ln \left(\frac{P_{\text {shakeout }}}{P_{F L C}}\right)=\frac{1}{1+e^{-\left(\alpha+\beta_{1} O C+\beta_{2} S+\beta_{3} M T B+\beta_{4} L+\beta_{5} R+\beta_{6} \Delta S+\beta_{7} C+\beta_{8} A g+\beta_{9} A T+\beta_{10} A D\right)}}$

$\operatorname{prob}($ shakeout $)=\frac{1}{1+e^{-\left(\alpha+\beta_{1} O C+\beta_{2} S+\beta_{3} M T B+\beta_{4} L+\beta_{5} R+\beta_{6} \Delta S+\beta_{7} C+\beta_{8} A g+\beta_{9} A T+\beta_{10} A D\right)}}$

68

Business Review: (2021) 16(2):60-76 


$$
\begin{aligned}
& \ln \left(\frac{P_{\text {delc }}}{P_{F L C}}\right)=\frac{1}{1+e^{-\left(\alpha+\beta_{1} O C+\beta_{2} S+\beta_{3} M T B+\beta_{4} L+\beta_{5} R+\beta_{6} \Delta S+\beta_{7} C+\beta_{8} A g+\beta_{9} A T+\beta_{10} A D\right)}} \\
& \operatorname{prob}(\text { decl })=\frac{1}{1+e^{-\left(\alpha+\beta_{1} O C+\beta_{2} S+\beta_{3} M T B+\beta_{4} L+\beta_{5} R+\beta_{6} \Delta S+\beta_{7} C+\beta_{8} A g+\beta_{9} A T+\beta_{10} A D\right)}}
\end{aligned}
$$

\section{Results and discussion}

\subsection{Descriptive summary}

The descriptive statistic in table 2 shows the sample N, which represents those companies that are listed in the Pakistan Stock Exchange. The model consists of 56 non-financial firms with yearly observations covering from 2011-2020. The total number of observations is 560. The descriptive statistics covers the mean, minimum, maximum, and standard deviation of all variables. The data was analyzed using STATA. 


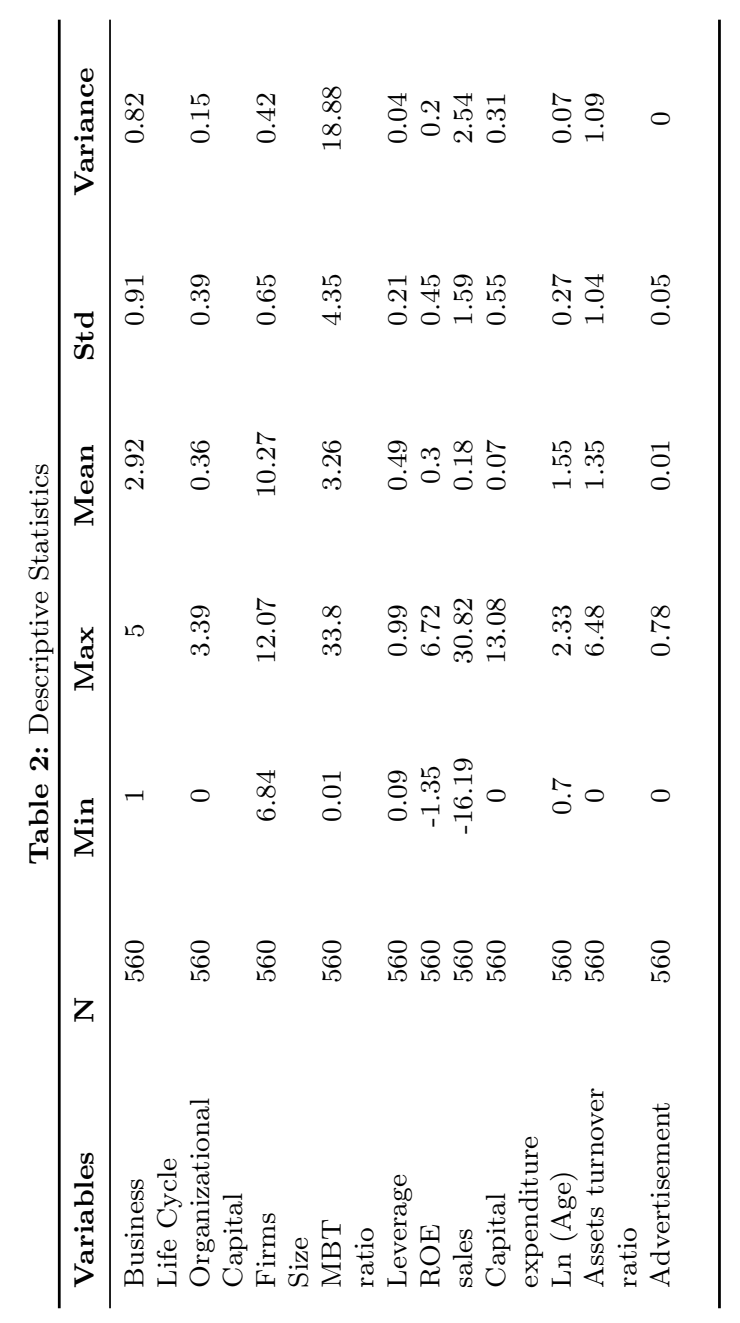


The results show the average of the Business Life Cycle is 2.92 with a minimum of 1 and a maximum value of 5 . The third row of the table shows that organizational capital, which is used as a dependent variable in the above table, shows that the average of organizational capital is 0.3585 with a minimum of 0.00006 and a maximum value is 3.38874 . The size of a firm is a control variable of a sample population, while the average firm size is 10.272. Similarly, the market to book ratio shows the average is 3.255 . The average leverage is 0.4888 . Additionally, the average return on equity is 0.3024 . The other variable is changed in sales whose average is 23.586. Capital expenditure is the 4th last control variable of current research, the result shows the average of capital expenditure, which is 0.0747 . The age of the firm average is 1.5527 . Moreover, the assets turnover ratio is the ninth control variable of that display average value is 1.3546. The end table explores the result of the last variable is a 0.1092 mean value.

\subsection{Pseudo R-square}

The table of pseudo-R-square explains that $24.5 \%$ variance of the dependent variable is explained by the set of the explanatory variable. Pseudo $\mathrm{R}$ square is used for a logistic model. For a model to be perfect, the Cox and Snell should be less than 1 (Nadeem et al 2021). By this method, the model of current research is perfect because the Cox and Snell amount is 0.245. Nagelkerke is an adjusted version of Cox and Snell and has a value of 0.266 , thereby supporting the idea that it is a perfect fit.

Table 3: Reporting Pseudo Square

\begin{tabular}{lc}
\hline $\begin{array}{l}\text { R-Square } \\
\text { Measures }\end{array}$ & Values \\
\hline $\begin{array}{l}\text { Cox and } \\
\text { Snell }\end{array}$ & 0.245 \\
Nagelkerke & 0.266 \\
McFadden & 0.111 \\
\hline
\end{tabular}

4.3 Organizational Capital and Business Life Cycle

Business Review: (2021) 16(2):60-76 


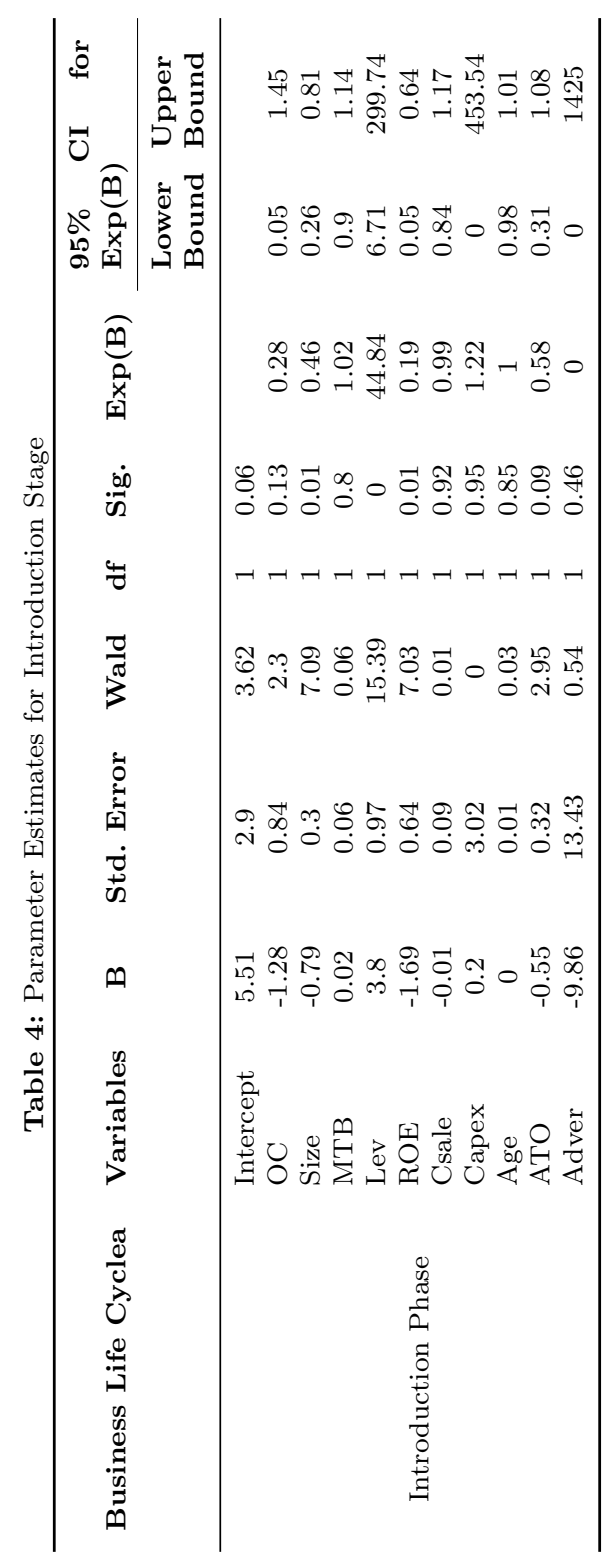


Multi-nomial logistic estimations produced in table 4. The mature stage of such Business Life Cycle is utilized as a basic classification when contrasted with certain other Business Life Cycle subcategories. The coefficient of organizational capital is -1.276 which is statistically insignificant. It suggests there's no link between organizational capital as well as the Business Life Cycle's introductory stage. The findings of current results are not a line with Hasan et al (2018) who have the opposite findings. The null hypothesis is accepted. The coefficient of size is -0.787 which is statistically significant. Therefore, a negative association indicates that there is an inverse relationship between size and the introduction stage of the Business Life Cycle. ROEs coefficient at the introduction phase of the Business Life Cycle is -1.689 which is highly significant. As a result, a reciprocal correlation involving ROE as well as the Business Life Cycle's introductory stage has been established.

The introductory stage has adversely correlated either size as well as ROE, meaning small as well as setback businesses belonged there. These findings are consistent with the prior results (Dickinson 2011; Pérez et al 2004; Shah et al 2021). The coefficient of MTB is 0.015 which is statistically insignificant. As a result, no link can be seen between the introductory stage of the business Life Cycle as well as MTB. However, the coefficient of leverage is 3.803 which is statistically significant. It means that there is indeed a strong link involving leverage as well as the Business Life Cycle's introductory stage. The coefficient of change in the sale is -0.009 which is statistically insignificant, indicating no link between the introductory stage of the Business Life Cycle and the $\Delta$ sale. The outcomes were in line with those of other research investigations (Hasan et al 2018; Leung et al 2018; Watson et al 2021; Zafar et al 2017).

The coefficient of Capex is 0.197 which is statistically insignificant. As a result, no link could be found between the introductory stage of the business Life Cycle as well as capital spending. The coefficient of firm age is -0.001 which is statistically insignificant indicating no relationship between the introduction phase of the Business Life Cycle-the age of the firm could be estimated. The ATO coefficient is -0.550 which is statistically significant. Consequently, a link is created between the introductory stage of the Business Life Cycle and thus the turnover ratio. The coefficient of advertisement expense is -9.858 which is statistically insignificant. Therefore, no link could be identified between the introductory stage of the business Life Cycle as well as advertising. 


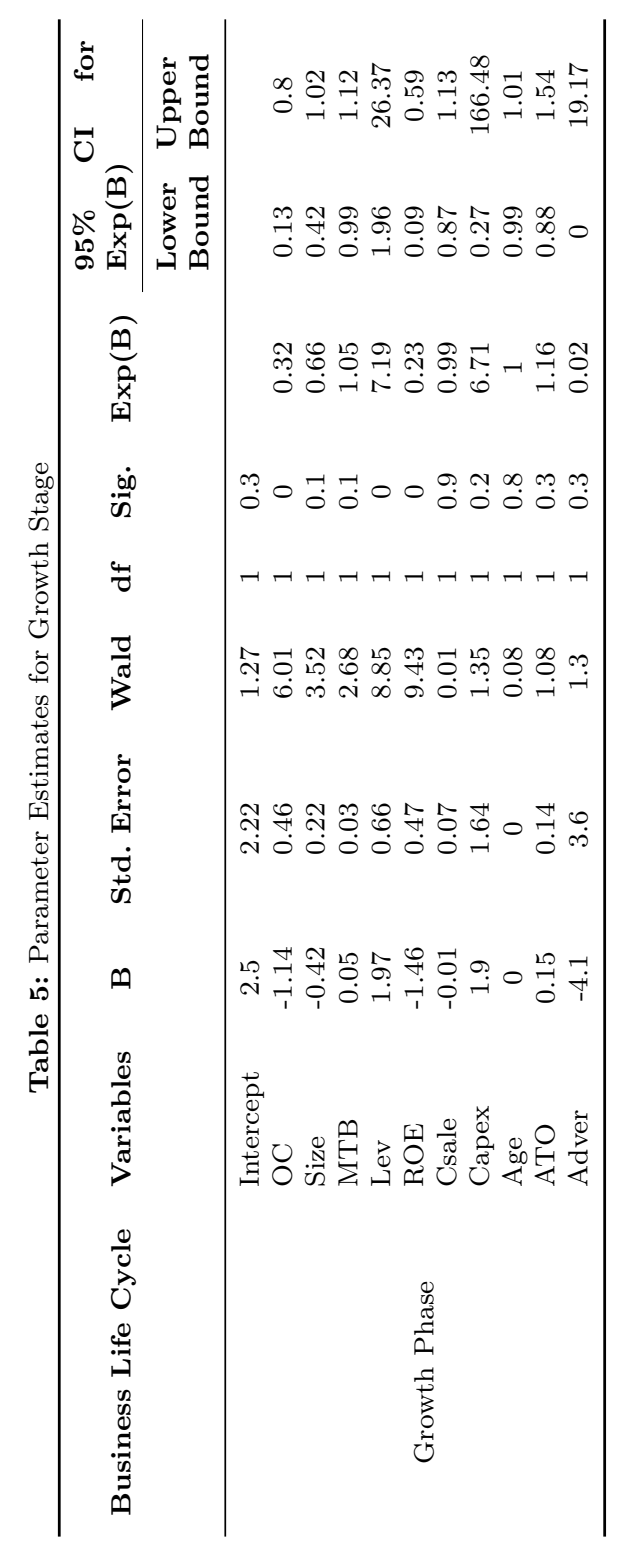


The second phase of the Business Life Cycle is growth is compared with the maturity phase of the firm. The coefficient of organizational capital is -1.135 which is highly significant. The results are a line with Eisfeldt and Papanikolaou (2013); Hasan et al (2018); Watson et al (2021). It implies that a company with a lower $\mathrm{OC}$ is more probable to have been in the growing stage of the Business Life Cycle. The alternative hypothesis is accepted. The coefficient of size is -0.420 which is statistically insignificant, indicating no correlation between size and the growth stage of the Business Life Cycle. The coefficient of MTB is 0.051 which is statistically insignificant, allowing no link to be established between the growth stage of the Business Life Cycle as well as MTB. Similarly, the coefficient of leverage is 1.973 , indicating higher significance levels. This establishes a strong link between leveraging and the growth stage of the Business Life Cycle. These outcomes are in line with previous research studies (Dickinson 2011; Habib and Hasan 2017).

The coefficient of ROE is - 1.456 highly significant indicating an inverse relationship between growth and ROEa finding supported by other studies (Habib et al 2018; Hasan and Habib 2017b; Shah et al 2021). The coefficient of change in the sale is -0.008 which is statistically insignificant. Therefore, no link could be seen between the growth stage of the Business Life Cycle and indeed the $\Delta$ sale. The coefficient of Capex is 1.903 which is insignificant. As a result, no link could be found between capital spending and indeed the growth stage of the Business Life Cycle. The coefficient of age is 0.001 which is statistically insignificant. Therefore, no link could be found between the growth stage of the business Life Cycle as well as age. The assets turnover ratio coefficient is 0.150 which is statistically insignificant. Consequently, no link could be seen between the growth stage of the Business Life Cycle as well as ATO. The advertisement expense coefficient is -4.101 which is statistically insignificant. Consequently, no link could been found between the growth stage of the Business Life Cycle as well as advertising spending. 


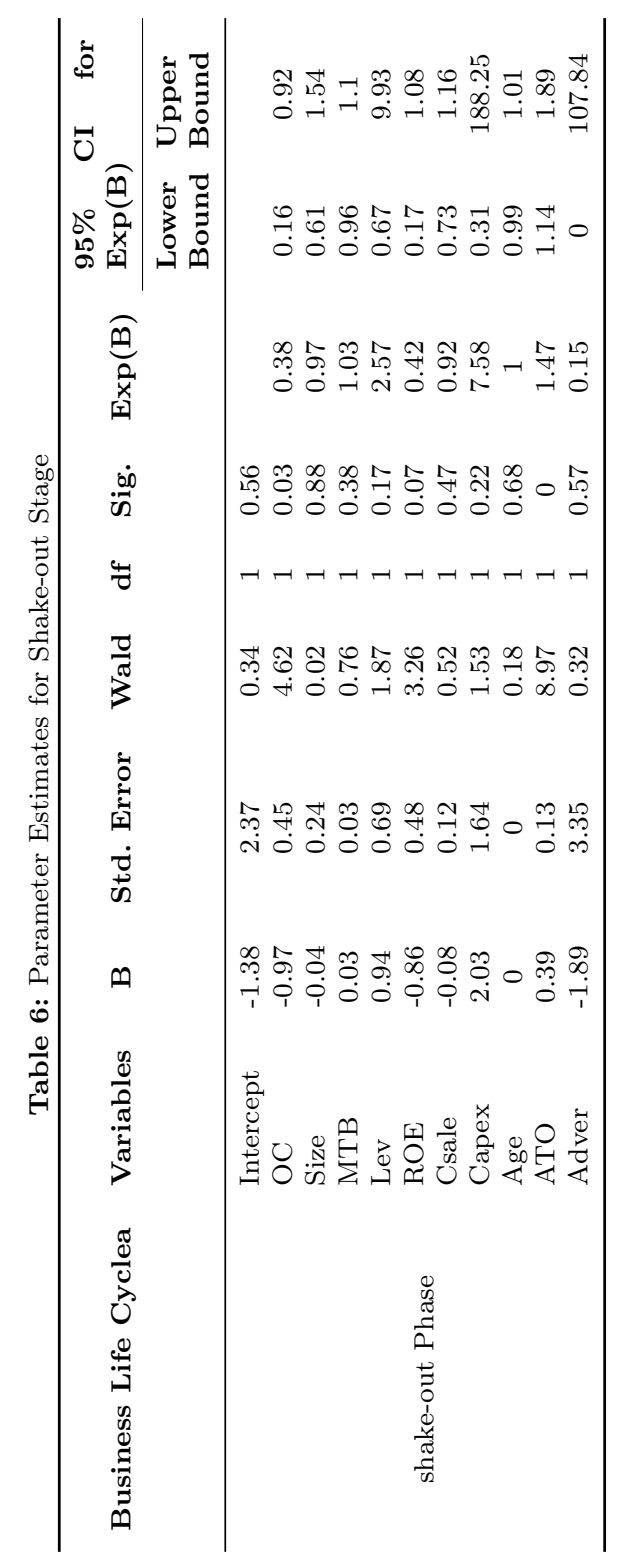


The next phase is shake-out the coefficient of organizational capital is -0.970 which is highly significant. the negative association between organizational capital and shake-out implies that there is a chance that the firm moves towards the reference category if $\mathrm{OC}$ is high. The size coefficient is -0.036 which is statistically insignificant, establishing no relationship between the shake-out stage of the business Life Cycle as well as the firm's size. The MB ratio's coefficient is 0.030 , which is insignificant as well. As a result, no link could be found between MTB and indeed the Business Life Cycle's shake-out stage. The coefficient of leverage is 0.944 which is insignificant. Therefore, no link could be found between leverage and indeed the Business Life Cycle's shake-out stage.

The coefficient of ROE is -0.864 which is significant. It implies that there is indeed a link between the Business Life Cycle's shake-out stage as well as ROE. The coefficient of change in the sale is -0.84 which is statistically insignificant, implying no link between the shake-out stage of the business Life Cycle as well as the firms $\Delta$ sales. The coefficient Capex is 2.025 which is insignificant. It suggests that there can be no link between capital expenditure and thus the shake-out stage of the Business Life Cycle. The firm age coefficient is -0.002 which is statistically insignificant. As a result, no link could be found between the shake-out stage of the business Life Cycle as well as the firm's age. The coefficient of assets turnover ratio is 0.385 highly significant. A link has been found between the shakeout stage as well as the ATO. The coefficient of advertisement expense is -1.887 which is statistically insignificant, implying no relationship between the shake-out stage of the Business Life Cycle and advertising spending. 


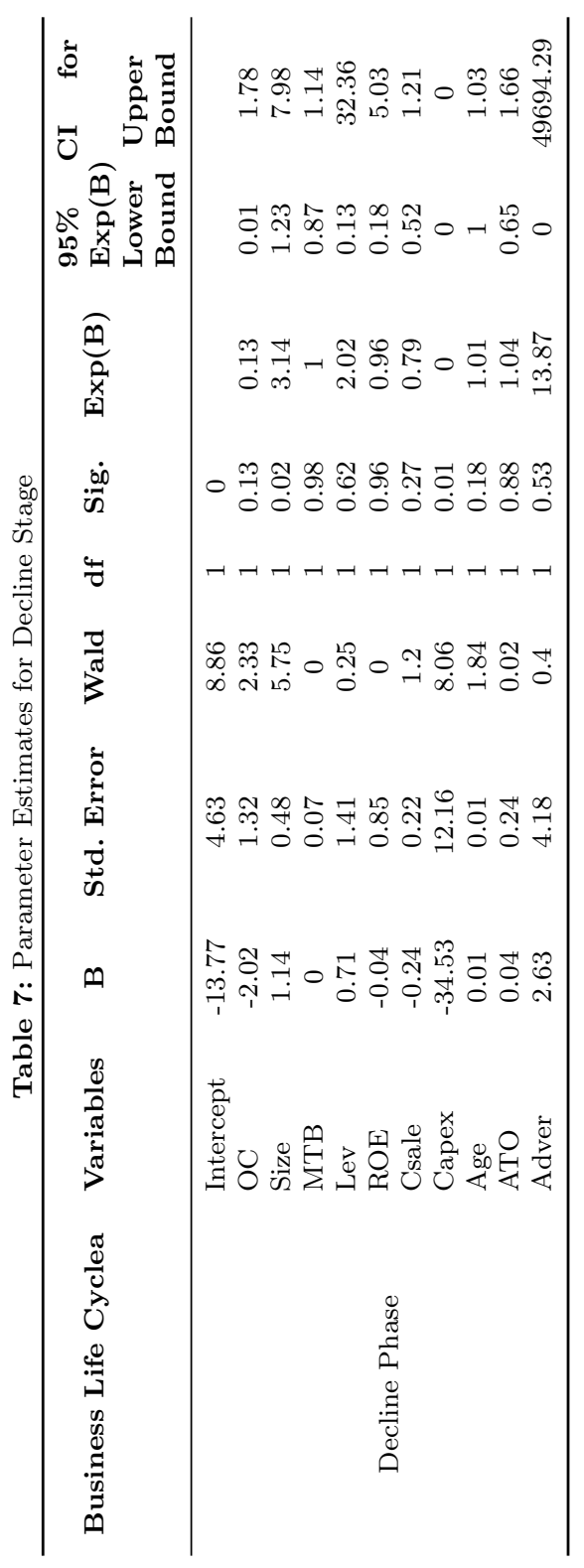


The last phase is declining, where the coefficient of organizational capital is -2.018 insignificant. The findings suggest that there can be no link between organizational capital as well as the Business Life Cycle's decline stage. The negative results are aligned with the argument of Eisfeldt and Papanikolaou (2013) and Saravia et al (2016) who were of the view that in comparison to organizational capital, corporations invest more of it in capital investment. The coefficient of size is 1.143 which is highly significant. As a result, a link was seen between the declining stage as well as the company's size has been developed. The positive association of the firm aligned with similar findings (Hasan and Habib 2017b; Nadeem et al 2021). MTB coefficient is -0.002 which is statistically insignificant. Therefore, no association between the decline phase of the Business Life Cycle and MTB can be established.

MTB coefficient is -0.002 which is statistically insignificant. Therefore, no association between the decline phase of the Business Life Cycle and MTB can be established. The coefficient of leverage is 0.705 which is statistically insignificant. As a result, no link could be found seen between the decline stage of the Business Life Cycle as well as leverage. ROE coefficient is - 0.042 which is statistically insignificant, establishing no relationship between the declining stage of the business Life Cycle as well as ROE. The change in sale coefficient is - -0.236 which is statistically insignificant, thereby establishing no link between the declining stage of the business Life Cycle as well as the $\Delta$ sale. The coefficient of capital expenditure is -34.526 highly significant. As a result, a negative correlation exists between the declining stage and capital expenditure. This finding is not a line with the different phases discussed by (Habib and Hasan 2017; Li et al 2021). The firm age coefficient is 0.11 which is statistically insignificant, resulting in no link between age as well as the decline stage of the Business Life Cycle. The coefficient of ATO is 0.37 which is statistically insignificant. As a result, there seems to be no link between ATO and the decline stage of the Business Life Cycle. The advertisement expense coefficient is 2.629 which is statistically insignificant. Consequently, there seems to be no link seen between the decline stage of the business Life Cycle as well as advertising.

\section{Conclusion}

The major goal of this research was to look at the organizational capital as well as stages of the Business Life Cycle using a group of PSX index businesses. To investigate the variations in results during different life cycle phases, the study has used a categorical data set of 56 non-financial listed firms of PSX index covering a period of ten years from 2011-2020 and multinomial logistic regression analysis was performed. The Business Life Cycle was used as an outcome variable; the independent variable was organizational capital with some control variables; size, $\mathrm{MB}$ ratio, leverage, $\mathrm{ROE}, \Delta$ sales, capital spending, companys age, the ratio of assets turnover, and advertisement expense. The Business Life Cycle contains five categories: introductory, growing, maturity, shake-out, and declining stage. Multinomial logistic model runs twice. In the first time, the study takes maturity as a reference category, which is compared with other cat- 


\section{Z. Bashir, G.A.Bhatti and S.Arshad}

egories and in second time shake-out phase is used as a reference category.

The findings reveal that organizational capital is unrelated to the Business Life Cycle's introductory stage. Distinct variables exhibit diverse effects on various phases of the Business Life Cycle. In the first stage size, ROE and ATO are negatively significant but leverage is positively significant which shows that a relationship exists between these variables and the introduction phase of the Business Life Cycle. The second phase is growth. According to growth with reference category, maturity organizational capital, size, and ROE is negatively associated with each other. The outcomes demonstrate an inverse association between these factors, with leverage being positively significant, indicating that leverage, as well as the growth stage of the Business Life Cycle, are linked.

Organization capital, as well as ROE, is negatively significant throughout the third step. However, ATO has a positive correlation. The maturing stage is utilized like a reference point in the last stage, and the size of an organization is positively connected with the declining stage of the Business Life Cycle even during the period of recession. The Capex is negatively significant which shows that there is an inverse relationship and there are more chances to move towards the reference category. In the next step, the current study used the shake-out phase as a reference category- the results show that leverage is positively associated during the introduction phase. Size and ATO are significant, but negatively associated which shows there is an inverse relationship between size and ATO during the introduction phase. During the maturity stage, organizational capital and ROE are positively significants, indicating direct relationship between organizational capital and the maturity phase.

The study concludes that the third and fourth hypothesis is accepted but the study failed to reject another hypothesis because the sample size of current research is not sufficient for such type of data. Moreover, SG\&A expenses for calculating OC stock are not a suitable measure for Pakistani firms. The practical and managerial implications of the study highlights the importance of maturity stage in the business life cycle where organizational capital can play a significantly positive role for the manufacturing firms in Pakistan. The remaining stages of business life cycle reported that organizational capital play a negative role. Therefore, the policymakers and decision makers in the non-financial companies,especially, manufacturing sector of Pakistan need to consider more organizational capital for maturity stage rather than other stages of business life cycle. Future research may be considered for the cross-industries listed in PSX in comparative mode to give more clear picture based on the present research model.

\section{References}

Akbar A, Akbar M, Tang W, Qureshi MA (2019) Is bankruptcy risk tied to corporate lifecycle? evidence from pakistan. Sustainability 11(3):678

Al-Hadi A, Chatterjee B, Yaftian A, Taylor G, Monzur Hasan M (2019) Corporate social responsibility performance, financial distress and firm life cycle: evidence from australia. Accounting \& Finance 59(2):961-989 
Atkeson A, Kehoe PJ (2005) Modeling and measuring organization capital. Journal of political Economy 113(5):1026-1053

Attig N, Cleary S (2014) Organizational capital and investment-cash flow sensitivity: The effect of management quality practices. Financial Management 43(3):473-504

Barclay MJ, Smith CW (2005) The capital structure puzzle: The evidence revisited. Journal of applied corporate finance $17(1): 8-17$

Bhattacharya D, Chang CW, Li WH (2020) Stages of firm life cycle, transition, and dividend policy. Finance Research Letters 33:101,226

Black SE, Lynch LM (2009) 6. Measuring Organizational Capital in the New Economy. University of Chicago Press

Carlin BI, Chowdhry B, Garmaise MJ (2012) Investment in organization capital. Journal of Financial Intermediation 21(2):268-286

Chan K, Guo RJJ, Wang YA, Yang HL (2019) Organization capital and analyst coverage

Cui H, Mak Y (2002) The relationship between managerial ownership and firm performance in high $\mathrm{r} \& d$ firms. Journal of corporate finance 8(4):313-336

DeAngelo H, DeAngelo L, Stulz RM (2006) Dividend policy and the earned/contributed capital mix: a test of the life-cycle theory. Journal of Financial economics 81(2):227-254

Dickinson V (2011) Cash flow patterns as a proxy for firm life cycle. The Accounting Review 86(6):1969-1994

Ding C, Ho CY, Chang M (2021) Ceo and cfo equity compensation and dividend payout over the firm lifecycle. Global Finance Journal 49:100,562

Eisfeldt AL, Papanikolaou D (2013) Organization capital and the cross-section of expected returns. The Journal of Finance 68(4):1365-1406

Evenson RE, Westphal LE (1995) Technological change and technology strategy. Handbook of development economics 3:2209-2299

Filatotchev I, Toms S, Wright M (2006) The firm's strategic dynamics and corporate governance life-cycle. International Journal of Managerial Finance

Flavin T, Goyal A, O'Connor T, et al (2020) Role of corporate governance and lifecycle in determining payout precommitment in an emerging economy. Tech. rep., Department of Economics, Finance and Accounting, National University of

Habib A, Hasan MM (2017) Firm life cycle, corporate risk-taking and investor sentiment. Accounting \& Finance 57(2):465-497

Habib A, Bhuiyan MBU, Hasan MM (2018) Firm life cycle and advisory directors. Australian Journal of Management 43(4):575-592

Hambrick DC, MacMillan IC, Day DL (1982) Strategic attributes and performance in the bcg matrixa pims-based analysis of industrial product businesses. Academy of Management Journal 25(3):510-531

Hasan MM, Habib A (2017a) Corporate life cycle, organizational financial resources and corporate social responsibility. Journal of Contemporary Accounting \& Economics 13(1):20-36

Hasan MM, Habib A (2017b) Firm life cycle and idiosyncratic volatility. International Review of Financial Analysis 50:164-175

Hasan MM, Al-Hadi A, Taylor G, Richardson G (2017) Does a firms life cycle explain its propensity to engage in corporate tax avoidance? European Accounting Review 26(3):469501

Hasan MM, et al (2018) Organization capital and firm life cycle. Journal of Corporate Finance 48:556-578

Helfat CE, Peteraf MA (2003) The dynamic resource-based view: Capability lifecycles. Strategic management journal 24(10):997-1010

Hsu FJ (2018) Does corporate social responsibility extend firm life-cycles? Management Decision

Jona-Lasinio C, Manzocchi S, Meliciani V (2019) Knowledge based capital and value creation in global supply chains. Technological Forecasting and Social Change 148:119,709

Jovanovic B (1982) Selection and the evolution of industry. Econometrica: Journal of the Econometric Society pp 649-670

Leung WS, Mazouz K, Chen J, Wood G (2018) Organization capital, labor market flexibility, and stock returns around the world. Journal of Banking \& Finance 89:150-168

Lev B, Radhakrishnan S (2009) 3. the valuation of organization capital. In: Measuring capital in the new economy, University of Chicago Press, pp 73-110

Lev B, Radhakrishnan S, Zhang W (2009) Organization capital. Abacus 45(3):275-298

Business Review: (2021) 16(2):60-76 
Li Q, Liu H, Zeng Y (2021) Size effect and growth options over firm lifecycle. Journal of Management Science and Engineering

Marwick A, Hasan MM, Luo T (2020) Organization capital and corporate cash holdings. International Review of Financial Analysis 68:101,458

Miller D, Friesen PH (1984) A longitudinal study of the corporate life cycle. Management science 30(10):1161-1183

Mueller DC (1972) A life cycle theory of the firm. The Journal of Industrial Economics pp 199-219

Nadeem M, Zaman R, Suleman T, Atawnah N (2021) Ceo ability, career concerns, firms lifecycle and investments in intellectual capital. International Review of Economics \& Finance 75:237-251

Pérez SE, Llopis AS, Llopis JAS (2004) The determinants of survival of spanish manufacturing firms. Review of Industrial Organization 25(3):251-273

Quinn RE, Cameron K (1983) Organizational life cycles and shifting criteria of effectiveness: Some preliminary evidence. Management science 29(1):33-51

Ren S, Song Z (2021) Intellectual capital and firm innovation: incentive effect and selection effect. Applied Economics Letters 28(7):617-623

Saravia J, Garcia C, Almonacid PM (2016) The determinants of systematic risk: A firm lifecycle perspective. Center for Research in Economics and Finance (CIEF), Working Papers (16-32)

Shah SAH, Shah TA, Ullah A, Yasir M (2021) Workplace deviance in public sector organizations: Evidence from pakistan. Journal of Applied Economics and Business Studies $5(1): 67-82$

Watson RT, Mathew SK, et al (2021) Capital, systems, and objects. Management for Professionals

Zafar S, Rahman A, Rizwan MF, Sohail MK (2017) Capital structure decision and firms life cycle-a study on non-financial sector of pakistan. NICE Research Journal of Social Science ISSN: 2219-4282 9:1-18 